\title{
Lysine as corrosion inhibitor for low alloy carbon steel in acidic media
}

\author{
Albana JANO*, Alketa LAME (GALO) and Efrosini KOKALARI (TELI)
}

Natural Sciences Faculty, Chemistry Department, Tirana University, Bulevardi Zogu i Parë, Tirana, Albania

\begin{abstract}
The use of inhibitors is one of the most practical means for protecting metals against corrosion, especially in acidic media. The interest is to use organic compounds as inhibitors due mainly to their inherent and non-toxic nature. Amino acids are attractive as corrosion inhibitors because they are nontoxic, relatively easy to produce with high purity at low cost, and are soluble in aqueous media. Lysine, one kind of amino acid is used as inhibitor. The aims of this study are to show corrosion protection efficiency of lysine and to explain the mechanism of corrosion. The experimental results demonstrated that the lysine offered protection for low alloy carbon steel in aggressive environments like $\mathrm{H}_{2} \mathrm{SO}_{4}$. Materials under investigation are two types of low alloy carbon steel marked as: Steel 39, Steel 44 (usually applied to concrete as reinforcing bars). The corrosion media consists in sulfuric acid in presence of chloride ions, in form of $\mathrm{NaCl}\left(\mathrm{H}_{2} \mathrm{SO}_{4} 1 \mathrm{M}+\mathrm{Cl}^{-} 10^{-3} \mathrm{M}\right)$. Potentiodynamic polarization methods are used for inhibitor efficiency testing. Potentiodymanic polarization measurements showed that the presence of lysine in acidic solution decreases the corrosion current to a good extent. The corrosion inhibition efficiency improves with the increase of the lysine concentration. The use of this inhibitor $(1 \mathrm{~g} / \mathrm{L})$ protects steel 39 in acidic media with $78.88 \%$ efficiency. That means lysine is a good corrosion inhibitor for these aggressive conditions.
\end{abstract}

Keywords: lysine, amino acid, steel bars, Tafel polarization.

\section{Introduction}

Steel is the most important engineering and construction material in the world. Corrosion problems have received a considerable amount of attention because of their attack on materials. The use of organic inhibitors in acidic solutions is widely used to prevent or minimize material loss during contact with acid. It has been reported that many inorganic, organic and heterocyclic compounds containing hetero atoms like $\mathrm{N}, \mathrm{O}, \mathrm{S}$ and $\mathrm{P}$ have been proved to be effective inhibitors for the corrosion of steel in acidic media [1].The aim of this paper was to study the corrosion protection efficiency of lysine and to explain the mechanism of corrosion.

\section{Experimental}

Materials under investigation were two marks of low alloy carbon steel respectively Steel 39 and Steel 44, intended for concrete armor. A polarization method such as potentiodynamic polarization was used for laboratory corrosion testing. This technique can provide significant useful information regarding the corrosion mechanisms, corrosion rate and corrosion protection efficiency of lysine. The potentiodynamic measurements were performed with Steel 39 and Steel 44. The samples used for the potentiodynamic measurements were prepared from steel bars of cylindrical shape with sizes $(D=6 \mathrm{~mm}$, 
$\mathrm{d}=4 \mathrm{~mm}$ ) and inside a Teflon tube having fixed with epoxy resin as shown in Fig. 1 [2,3].

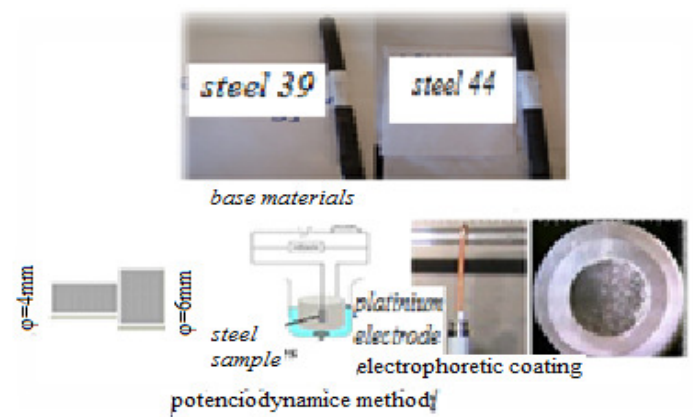

Fig.1. Preparing of the samples for potentiodynamic measurements.

For the potentiodynamic measurements the steel samples, before the Teflon tube was fixed inside, were polished with emery paper (250-1000), then subjected to cleaning with distilled water, drying, degreasing with acetone, cleaning with distilled water again and finally drying. To avoid the influence of crevice corrosion in electrochemical measurements, the samples were pre-coated with electrophoretic coating [3]. The chemical composition of the low alloy carbon steel is presented in Table 1.

Table 1. Composition of low alloy carbon steel tested

\begin{tabular}{|c|c|c|}
\hline Element & $\begin{array}{c}\text { Steel 39 } \\
\text { \% w/w }\end{array}$ & $\begin{array}{c}\text { Steel 44 } \\
\text { \% w/w }\end{array}$ \\
\hline $\mathbf{C}$ & 0.37 & 0.445 \\
\hline $\mathbf{S i}$ & 0.17 & 0.348 \\
\hline $\mathbf{M n}$ & 0.51 & 0.780 \\
\hline $\mathbf{C r}$ & 0.60 & 0.118 \\
\hline $\mathbf{N i}$ & 0.60 & 0.263 \\
\hline $\mathbf{C u}$ & 0.30 & 0.324 \\
\hline $\mathbf{P}$ & 0.040 & 0.0720 \\
\hline $\mathbf{S}$ & 0.040 & 0.0440 \\
\hline
\end{tabular}

The corrosion media consists in sulfuric acid in presence of chloride ions, in form of $\mathrm{NaCl}\left(\mathrm{H}_{2} \mathrm{SO}_{4}\right.$ $\left.1 \mathrm{M}+\mathrm{Cl}^{-} 10^{-3} \mathrm{M}\right)$. Lysine was used as inhibitor , an alpha amino acid, which contains carboxyl and amino groups bonded to the same carbon (Fig.2).

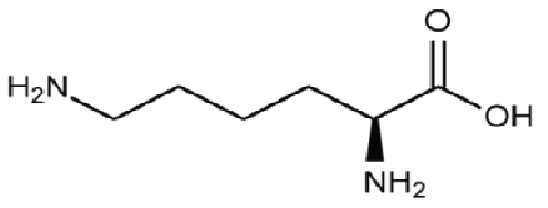

Fig.2. The structure of lysine.

The matrix of the potentiodynamic measurements is presented in Table 2 .

Table 2. The matrix for potentiodynamic measurements

\begin{tabular}{|c|c|c|c|c|c|}
\hline \multirow{2}{*}{$\begin{array}{c}\text { Test } \\
\text { number }\end{array}$} & \multicolumn{5}{|c|}{ Lysine Concentrations (g/L) } \\
\cline { 2 - 6 } & Blank & 0.25 & 0.5 & 0.75 & 1 \\
\hline 1 & + & & & & \\
\hline 2 & & + & & & \\
\hline 3 & & & + & & \\
\hline 4 & & & & + & \\
\hline 5 & & & & & + \\
\hline
\end{tabular}

Electrochemical measurements.

Potentiodynamic measurements were carried out in a typical three-electrode electrochemical cell with an $\mathrm{Hg} / \mathrm{Hg}_{2} \mathrm{SO}_{4}$ electrode as a reference electrode, a platinum electrode as auxiliary electrode. The working electrode was steel 39 and steel 44.

Potentiostat galvanostat type TACUSSEL PJT 24-2 was used for potentiodynamic measurements. Potential scan rate was $3 \times 10^{-2} \mathrm{~V} / \mathrm{min}[3,4]$.

Deaeration of the solution was realized during the potentiodynamic measurements using a stream of pure nitrogen inside the solution for $30 \mathrm{~min}$ and above solution for $5 \mathrm{~min}$. Corrosion current density was determined using the cutting point of Tafel extrapolation line and $\mathrm{v}_{\text {corr }}$ was calculated according to Faraday's law [3,5]:

$$
V_{c o r r}=(K * a * i) /(n * D)
$$

where a represents the atomic weight of the metal $(\mathrm{a}=56 \mathrm{~g} / \mathrm{mol}), \mathrm{i}$ - corrosion current density in $\left(\mu \mathrm{A} / \mathrm{cm}^{2}\right), \mathrm{n}-$ the number of electrons exchanged during metal dissolution $(n=2), D$-the density in $\left(\mathrm{g} / \mathrm{cm}^{3}\right)\left(\mathrm{D}=7.86 \mathrm{~g} / \mathrm{cm}^{3}\right)$ and $\mathrm{K}$ is a constant which 
equals to 0.00327 if corrosion rate $\left(\mathrm{V}_{\text {corr }}\right)$ is calculated in $[\mathrm{mm} / \mathrm{y}]$.

The corrosion inhibitor efficiency was calculated using the formula number (2) [6]:

Inhibitor Efficiency $(\%)=[(C R$ uninhibited $-C R$ inhibited)/CR uninhibited] $\times 100$

where: CR uninhibited - is the corrosion rate of the uninhibited system, CR inhibited - is the corrosion rate of the inhibited system.

\section{Results and Discussions}

The potentiodynamic polarization behavior of steel 39 in $1 \mathrm{M} \mathrm{H}_{2} \mathrm{SO}_{4}$ solution with $10^{-3} \mathrm{M}$ chloride ions in the absence and in the presence of different concentrations of lysine is shown in Fig. 3. Figure 4 represents the potentiodynamic polarization curves and the corresponding average Tafel extrapolation lines in the presence of $1 \mathrm{~g} / \mathrm{L}$ lysine for low alloy carbon steel 39 under investigation (best case).

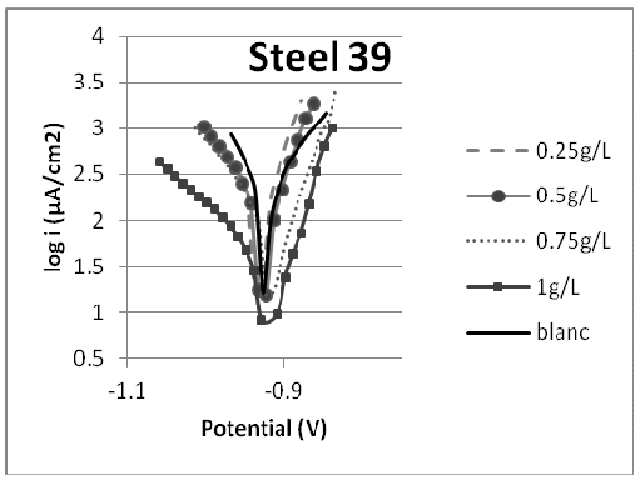

Fig. 3. Potentiodynamic curves for Steel 39 in de-aerated $1 \mathrm{M} \mathrm{H} \mathrm{H}_{2} \mathrm{SO}_{4}$ solution with $10^{-3} \mathrm{M}$ chloride ions (blank) with and without inhibitor.

The increase of the inhibitor concentration 0.25 $\mathrm{g} / \mathrm{L}, 0.5 \mathrm{~g} / \mathrm{L}, 0.75 \mathrm{~g} / \mathrm{L}$ and $1 \mathrm{~g} / \mathrm{L}$; shifts $\mathrm{E}_{\text {corr }}$ towards more positive direction, indicating the effectiveness of lysine as inhibitor.

Particularly, the cathodic reaction is inhibited to larger extent than the anodic reaction.

The potetiodynamic polarization curves from Fig. 3 show that the presence of lysine decreases the corrosion rate. The corrosion rates $(\mathrm{mm} /$ year) and protection efficiency values using different concentration of lysine are presented in Table 3.

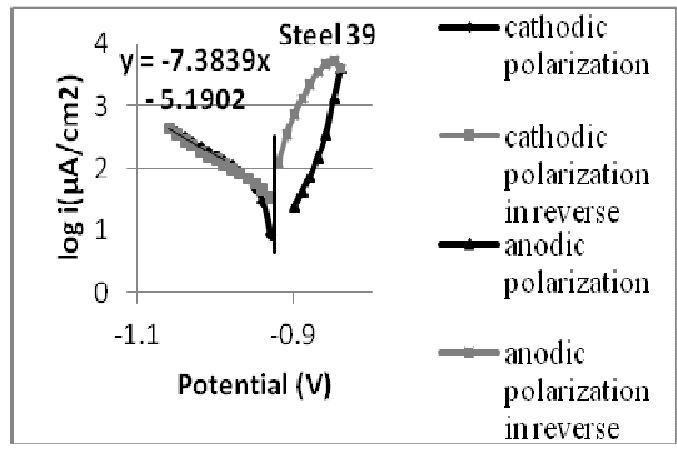

Fig. 4. Potentiodynamic curves and Tafel extrapolations for Steel 39 in de-aerated $1 \mathrm{M}$ $\mathrm{H}_{2} \mathrm{SO}_{4}$ solution with $10^{-3} \mathrm{M}$ chloride ions in presence of $1 \mathrm{~g} / \mathrm{L}$ lysine.

The adsorption mechanism for a given inhibitor depends on such factors, as the nature of metal corrosion medium, the $\mathrm{pH}$ and the concentration of the inhibitor as well as the functional groups present in its molecule [7].

Table 3. Corrosion rate and protection efficiency for Steel 44 and Steel 39 in de-aerated $1 \mathrm{M} \mathrm{H}_{2} \mathrm{SO}_{4}$ solution with $10^{-3} \mathrm{M}$ chloride ions, with and without inhibitor.

\begin{tabular}{|c|c|c|c|c|}
\hline \multirow{2}{*}{$\begin{array}{c}\text { Conc. } \\
\text { of } \\
\text { lysine, } \\
\mathrm{g} / \mathrm{L}\end{array}$} & \multicolumn{3}{|c|}{ Mark of steel material } \\
\cline { 2 - 5 } & $\begin{array}{c}\mathrm{V}_{\text {corr }} \\
\mathrm{mm} / \\
\text { year }\end{array}$ & $\begin{array}{c}\text { Prot.Eff., } \\
\%\end{array}$ & $\begin{array}{c}\mathrm{V}_{\text {corr }}, \\
\mathrm{mm} / \\
\text { year }\end{array}$ & $\begin{array}{c}\text { Prot.Eff., } \\
\%\end{array}$ \\
\hline Blank & 2.32 & - & 3.31 & - \\
\hline 0.25 & 1.89 & 18.53 & 3.37 & 1.81 \\
\hline 0.5 & 1.82 & 21.55 & 2.88 & 12.99 \\
\hline 0.75 & 1.06 & 54.31 & 2.17 & 34.44 \\
\hline 1 & 0.49 & 78.88 & 1.03 & 68.88 \\
\hline
\end{tabular}

The corrosion inhibition process is based on the adsorption of the amino acid molecules on the active sites and/or deposition of the corrosion products on the alloy surface $[8,9]$. The atoms of $\mathrm{O}$ and $\mathrm{N}$ from lysine molecule serve as active centers for the 
process of the amino-acid adsorption on the metal surface. Availability of no bonded (lone pair) and pelectrons in inhibitor molecules facilitates electron transfer from the inhibitor to the metal. A coordinate covalent bond involving transfer of electrons from inhibitor to the metal surface may be formed. The strength of the chemisorptions bond depends upon the electron density on the donor atom of the functional group and also on the polarizability of the group. When an $\mathrm{H}$ atom attached to the $\mathrm{C}$ in the ring is replaced by a substituent group $\left(-\mathrm{NH}_{2}\right.$, or $\mathrm{COOH})$ it improves inhibition [10]. In Fig. 5 the mechanism of corrosion inhibition by amino acids is presented.

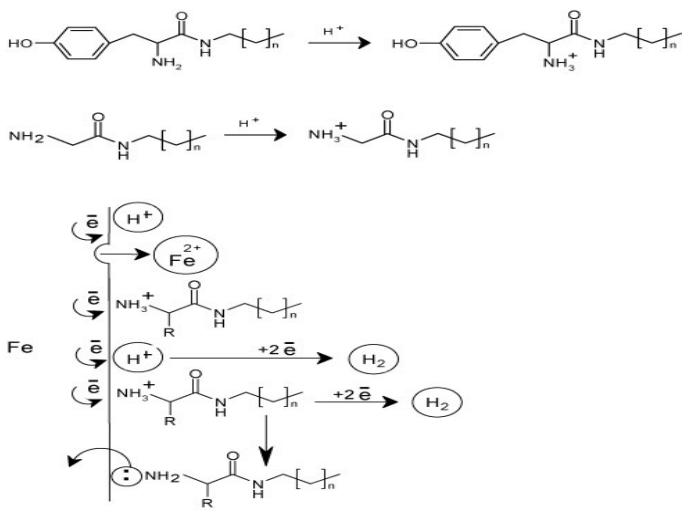

Fig. 5 .The mechanism of inhibition of amino acids.

The increase of inhibition efficiency with the increase of amino acid concentration indicates that more lysine molecules are adsorbed on the metal surface at higher concentration, leading to greater surface coverage.

\section{Conclusions}

Lysine is a good inhibitor in $1 \mathrm{M} \mathrm{H}_{2} \mathrm{SO}_{4}$ in presence of $\mathrm{Cl}^{-}$and the corrosion inhibition efficiency of lysine increases with the increase of its concentration.

Potentiodynamic polarization methods show that Steel 39 presents higher sustainability against corrosion in this aggressive media.

The corrosion rate of Steel 39 is the lowest, compared to steel 44 , being $2.32 \mathrm{~mm} /$ year in the absence of the inhibitor. The presence of the inhibitor (lysine) significantly lowers the corrosion rate.

Lysine mitigates the corrosion rate of the Steel 39 from $2.32 \mathrm{~mm} /$ year to $0.49 \mathrm{~mm} /$ year with a protection efficiency of $78.88 \%$ (best case: $1 \mathrm{~g} / \mathrm{L}$ inhibitor).

\section{References}

* E-mail address: janoalbana@yahoo.com

[1]. P.Selvakumar, B.Balanaga Karthik, and C.Thangavelu, Journal Of Advances In Chemistry, 3(4), 87-95 (2013).

[2]. M. Abdallah, Portugaliae Electrochimica Acta 22, 161-175 (2004).

[3]. M. G. Fontana, Corrosion Engineering, McGraw-Hill, 1986.

[4]. R. G. Kelly, J. R. Scully, D. W. Shoesmith and R. G. Buchheit, Electrochemical Techniques in Corrosion Science and Engineering, CRC Press, 2002.

[5]. E. Bardal, Engineering Materials and Processes, Corrosion and Protection, Springer-Verlag, 2004.

[6]. E. G. Azero, L. L. Lopes and C. T. Andrade, Polymer Bulletin 39, 621 - 625 (1997)

[7]. E.E. Oguzie, Y.Li and F.H. Wang, J., Colloid Interface Science 310, 90-98(2007).

[8]. W.A. Badawy K.M. Ismail and A.M. Fathi, Applied Electrochemistry. 35, 879-888 (2005).

[9]. G. Bereket and A. Yurt, Corrosion Science 43, 1179-1195 (2001).

[10]. Azza El-Sayed El-Shenawy, Journal of American Science, 7(6), 600-605 (2011).

Submitted: February $18^{\text {th }} 2014$ Accepted in revised form: March $28^{\text {th }} 2014$ 